\title{
First record of Microplitis rufiventris Kokujev, 1914 (Braconidae: Microgastrinae) from Iran
}

\author{
Samira Farahani ${ }^{1}$, Ali Asghar Talebi ${ }^{1 *}$, Cornelis van Achterberg ${ }^{2}$ and Ehsan Rakhshani ${ }^{3}$ \\ 1 Department of Entomology, Faculty of Agriculture, Tarbiat Modares University, P. O. Box 14115-336, Tehran, Iran. \\ 2 Senior Researcher \& Curator Hymenoptera, Department of Terrestrial Zoology, Netherlands Centre for Biodiversity Naturalis, Postbox 9517, \\ 2300 RA Leiden, The Netherlands. \\ 3 Department of Plant Protection, College of Agriculture, University of Zabol, P. O. Box 98615-538, Zabol, Iran. \\ * Corresponding author. E-mail: talebia@modares.ac.ir
}

\begin{abstract}
Occurrence of the genus Microplitis Forster (Braconidae, Microgastrinae) was surveyed in the Northern part of Iran. The specimens were collected using Malaise traps during 2010-2011. Two species, Microplitis rufiventris Kokujev, 1914 and M. ochraceus Szepligeti, 1896 were collected and identified of which the first species is newly recorded from Iran. Diagnostic characters and geographical distribution of the species are briefly discussed.
\end{abstract}

Microgastrinae Förster, 1862 is one of the largest subfamilies of Braconidae (Hymenoptera: Ichneumonoidea) (van Achterberg 1976). All species attack and develop in larval stage of insects especially Lepidoptera and Coleoptera and exit from the host to pupate (Shaw and Huddleston 1991). Microgastrinae comprises more than 2,197 described species worldwide (Yu et al. 2012). The tribe Microplitini Mason, 1981 included four genera, i.e., Alloplitis Nixon, 1965, Microplitis Förster, 1862, Philoplitis Nixon, 1965 and Snellenius Westwood, 1882, of which only Microplitis is represented in the west Palaearctic region (Yu et al. 2012).

The genus Microplitis comprises a moderately small group, but the species have a worldwide distribution (Yu et al. 2012). This genus includes 178 described species worldwide, and approximately 77 species are found in the Palaearctic region (Yu et al. 2012). Member of the genus Microplitis are endoparasitoids of Lepidoptera, mainly Noctuidae (Wilkinson 1930; Yu et al. 2012; Gupta 2013). Janzen et al. (2003) studied the host specificity and hyperparasitism associated with Microplitis species in relation to sphingid hosts.

The genus Microplitis was formerly classified under the genus Microgaster Latreille, 1804 with the type species Microgaster sordipes Nees (Telenga 1955). Species of the genus Microplitis were transferred to the new genus Glabromicroplitis by Papp $(1979,1986)$. Nixon (1965) reclassified and reorganized the subfamily Microgastrinae. According to the subsequent studies, the genus Glabromicroplitis has been determined as a junior synonym of Microplitis (Austin and Dangerfield 1993). The genus can be recognized by the roughly sculptured propodeum, having a large areolet, shape and sculpture of the first metasomal tergite, and by the existence of a weak suture separating the second and third tergum (Mason 1981; Austin and Dangerfield 1993; Song and Chen 2008). Nixon (1970) revised 28 European Microplitis species. The Palaearctic species of the Microplitis were revised and keyed by Papp (1984), who recorded a total 68 species with description of seven new species. Gupta (2013) revised Indian Microplitis species and described one new species.

Not much research has been done on the fauna of Microplitis in Iran. So far, six species of Microplitis have been recorded from Iran (Telenga 1955; Nixon 1968; Shenefelt 1973; Tobias 1976; Papp 1984; Fallahzadeh and Saghaei 2010; Ghahari et al. 2011a,b; Rastegar et al. 2012). Here, we present the first record of Microplitis rufiventris Kokujev, 1914 from Iran.

Study material was collected from different habitats of Northern Iran during March to November of 2010 and 2011 using Malaise traps. The specimens were taken from the traps at weekly intervals. Later the dried specimens were card-mounted and labelled. Identifications were performed using keys by Papp (1984) and Tobias et al. (1986). The photographs were taken using an Olympus SZX9 stereomicroscope equipped with a Sony CCD digital camera. Morphological terminology follows van Achterberg (1993). The specimens are deposited in the insect collection of the Department of Entomology, Tarbiat Modares University, Tehran, Iran and the Naturalis Biodiversity Center, Leiden, Netherlands.

A total of 166 and 29 specimens of Microplitis rufiventris and M. ochraceus were collected from the studied area, respectively.

\section{Microplitis ochraceus Szepligeti, 1896 (Figure 1 A-C)}

Material examined: Alborz province, Karadj (35 $46^{\prime}$ $\mathrm{N}, 50^{\circ} 56^{\prime}$ E, $1277 \mathrm{~m}$ a.s.l.), 05-13.vii.2010, 19; Tehran province, Shahriar $\left(35^{\circ} 40^{\prime} \mathrm{N}, 50^{\circ} 56^{\prime} \mathrm{E}, 1168 \mathrm{~m}\right.$ a.s.l.), 07-14.vi.2010, 10̂; 12-19.vii.2010, 1q; 19-27.vii.2010, 1ㅇ; 30.viii-06.ix.2010, 2 우우 06-13.ix.2010, 6우, 1ㅎ;

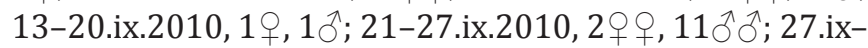
04.x.2010, 1 ; ; leg. A. Nadimi.

Diagnosis (Female): Body length $3.5-4.0 \mathrm{~mm}$, pterostigma brown with pale yellow spot basally, vein $1-\mathrm{SR}+\mathrm{M}$ of fore wing straight (Figure 1C); mesonotum and scutellum rugose (Figure 1B); first metasomal tergite strongly broadening posteriorly, as long as its width, completely rugose, second tergite rugose (Figure 1B); 
body reddish yellow (Figure 1A), mesosoma sometimes with variable blackish pattern.

Biology: Microplitis ochraceus has been recorded as a parasitoid of the Lead-coloured Drab, Orthosia populeti (Fabricius, 1781) (Lepidoptera: Noctuidae) (Györfi 1959).

Distribution: Azerbaijan, Greece, Hungary, Kazakhstan, Moldova, Mongolia, Russia, Ukraine (Yu et al. 2012), Iran (Telenga 1955).

\section{Microplitis rufiventris Kokujev, 1914 (Figure 2 A-C)}

Material examined: Alborz province, Karadj $\left(35^{\circ} 46^{\prime}\right.$ $\mathrm{N}, 50^{\circ} 56^{\prime}$ E, $1277 \mathrm{~m}$ a.s.l.), 15-22.vi.2010, 10ْ; Tehran province, Shahriar $\left(35^{\circ} 40^{\prime} \mathrm{N}, 50^{\circ} 56^{\prime} \mathrm{E}, 1168 \mathrm{~m}\right.$ a.s.l. $), 24-$ 31.viii.2010, 4웅 31.viii-07.ix.2010, 10웅, 5へすへ; 07-14.

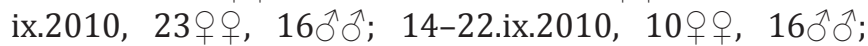
22-28.ix.2010, 14오, 34へో; 28.ix-05.x.2010, 3우,

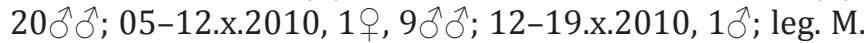
Khayrandish.

Diagnosis (Female): Body length 2.8-3.5 mm; pterostigma dark brown with pale yellow spot basally, vein $1-S R+M$ of fore wing slightly curved (Figure 2C); mesonotum rugose, scutellum more or less shiny (Figure 2B); first metasomal tergite sub-parallel sided and
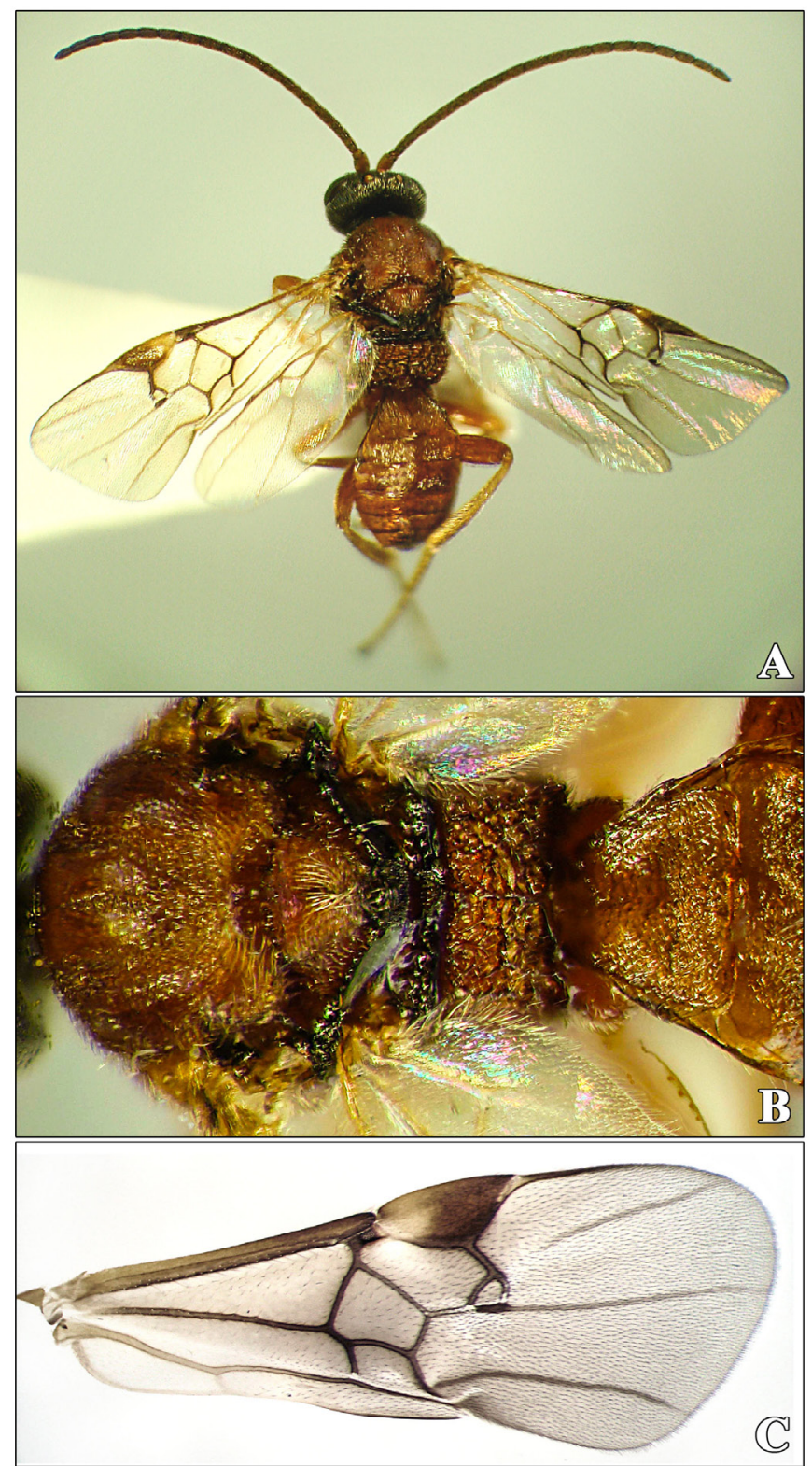

FIGURE 1. Microplitis ochraceus Szepligeti, 1896: A. Habitus, dorsal view, B. Mesosoma and part of metasoma, C. Fore wing. rounded at apex, about twice times as long as its medial width, smooth and shiny or weakly sculptured, second tergite smooth (Figure 2B); head and mesosoma black, metasoma reddish yellow except apex black (Figure 2A).

Biology: This species is a solitary endoparasitoid of Helicoverpa armigera (Hübner, 1809), Spodoptera cilium (Guenée, 1852), S. exigua (Hübner, 1808) and S. littoralis (Boisduval, 1833) (Yu et al. 2012). This species is known as a biological control agent against Spodoptera frugiperda (Smith, 1797) (Coulson 1994). In the field, this parasitoid shows preference towards early larval instars (late first to early fourth) (Hegazi et al. 2013). Some aspects of the reproductive biology of $M$. rufiventris were documented by Hegazi et al. (2007).

Distribution: Afghanistan, China, Cyprus, Egypt, Israel, Jordan, Romania, Turkey, Turkmenistan, Uzbekistan (Yu et al. 2012). New record form Iran.

The specimens were collected using 32 Malaise traps. The Malaise traps were placed in different habitats such as forests, pastures and orchards. Our study showed that
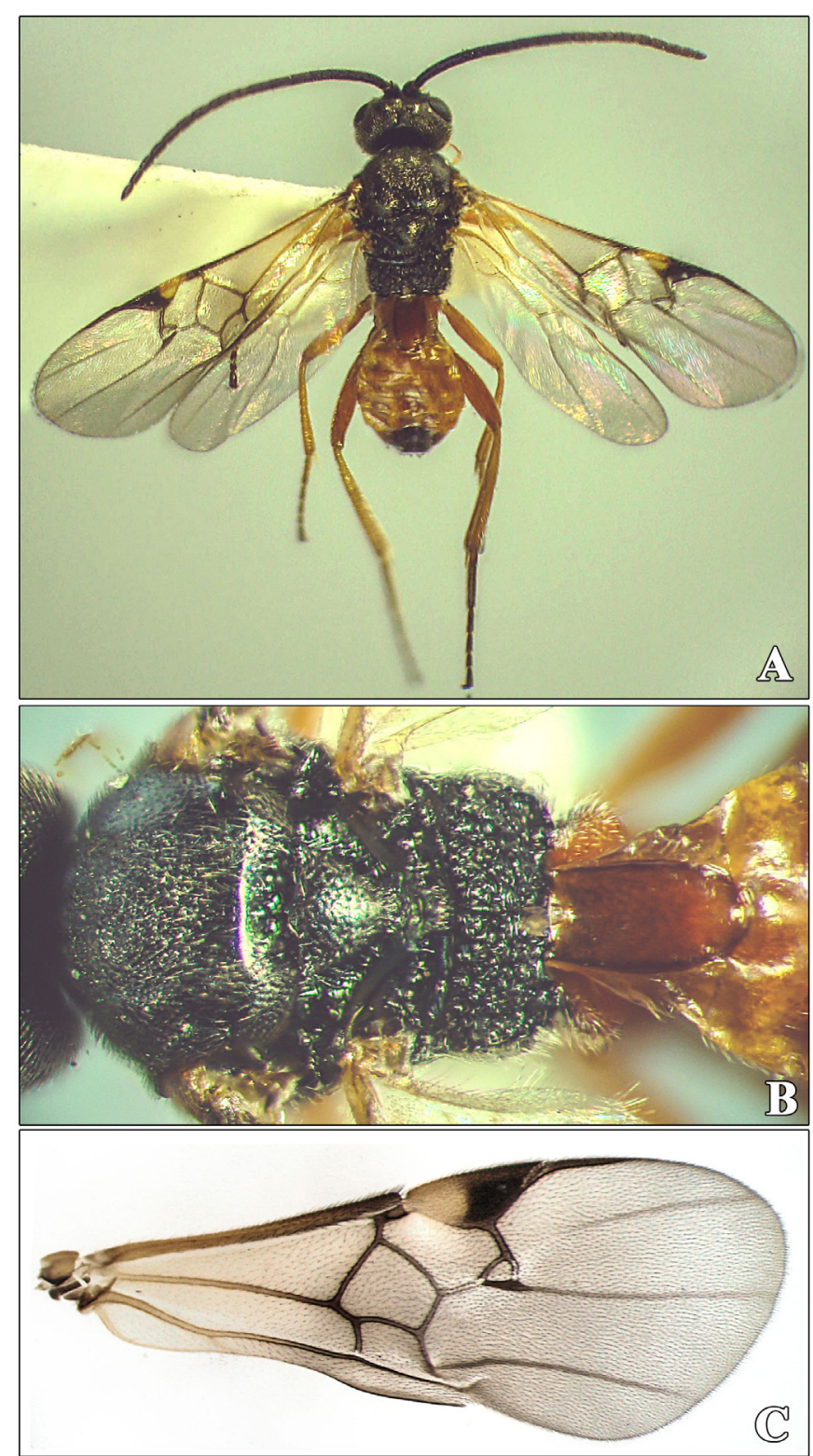

Figure 2. Microplitis rufiventris Kokujev, 1914: A. Habitus, dorsal view, B. Mesosoma and part of metasoma, C. Fore wing. 
Microplitis rufiventris and M. ochraceus were only found in Tehran (Shahriar) and Alborz (Karadj) provinces. Both these regions consist of cultivated crops and orchards. Hence these parasitoids are acting as natural biological control agents of the most important pests in these regions and this biological activity can be later harnessed at a much larger scale through mass production if need arises. According to our sampling, most of the specimens were captured from June to October and both species were active during the growing season.

Acrolyta stroudi Gauld (Ichneumonidae) and Conura convergea Delvare (Chalcididae) have been recorded as hyperparasitoids of Microplitis from Costa Rica (Janzen et al. 2003).

Among the neighboring countries of Iran, the records of Microplitis are still restricted to M. mediator (Haliday) and M. spectabilis (Haliday) from Pakistan (Cameron 1906;
Khan 1999), M. rufiventris Kokujev, M. strenuous Reinhard and M. tadzhicus Telenga from Afghanistan (Hedwig 1961; Tobias et al. 1998), M. erythogaster Abdinbekova, M. spinolae (Nees) and $M$. tazhicus from Tajikistan (Telenga 1949; Tobias and Saidov 1992), while about 30 species have been recorded from Turkey (Inanç 1997, 2002; Inanç and Beyarslan 1997, 2001; Beyarslan et al. 2002) and Russia (Telenga 1955; Tobias 1971, 1976; Tobias et al. 1986; Papp 1984; Kotenko 1994). So far, seven species of this genus are known from Iran (Table 1) (M. aduncus (Ruthe, 1860), M. deprimator (Fabricius, 1798), M. ochraceus Szépligeti, 1896, M. rufiventris Kokujev, 1914, M. scrophulariae Szépligeti, 1898, M. spectabilis (Haliday, 1834) and M. viduus (Ruthe, 1860)) and comprises about $9 \%$ of the species of Palaearctic fauna. Iran is a large country, incorporating various geographical regions and climates, indicating a need for further studies.

TABLE 1. Updated list of Microplitis species recorded from Iran.

\begin{tabular}{lll}
\hline Microplitis species & Distribution in Iran (provinces) & References \\
\hline M. aduncus (Ruthe, 1860) & Province not defined & Papp (1984) \\
M. deprimator (Fabricius, 1798) & Province not defined & Nixon (1968) \\
M. ochraceus Szépligeti, 1896 & Ardabil province (Mugan) & Telenga (1955) \\
M. rufiventris Kokujev, 1914 & Tehran and Alborz provinces & This study \\
M. scrophulariae Szépligeti, 1898 & Pehran and Alborz provinces & This study \\
& Isfahan province (Kashan) & Tobias (1976) \\
M. spectabilis (Haliday, 1834) & Isfahan province & Ghahari et al. (2011b) \\
M. viduus (Ruthe, 1860) & East Azarbaijan province & Ghahari et al. (2011b) \\
\hline
\end{tabular}

ACKNOWLEDGMENTS: Thanks to the Department of Entomology, Tarbiat Modares University for providing financial support for this study. We are also grateful to two anonymous reviewers for their valuable comments on the earlier version of this paper and Dr. D. Yu for sending valuable papers. Many thanks to Dr. Ahmad Nadimi and Mohammad Khayrandish for helping us in the trapping and collecting specimens.

\section{Literature Cited}

Austin, A.D and P.C. Dangerfield. 1993. Systematics of Australian and New Guinean Microplitis Foerster and Snellenius Westwood (Hymenoptera: Braconidae: Microgastrinae), with a review of their biology and host relationships. Invertebrate Taxonomy 7: 1097-1166.

Beyarslan, A., F. Inanç, O. Cetin and M. Aydogdu. 2002. Braconiden von den tuerkischen Inseln Imbros und Tenedos (Hymenoptera, Braconidae: Agathidinae, Braconinae, Cheloninae, Microgastrinae). Entomofauna 23(15): 173-188.

Cameron, P. 1906. On the Tenthredinidae and parasitic Hymenoptera collected in Baluchistan by Major C. G. Nurse. Part I. Journal of the Bombay Natural History Society 17: 89-107.

Coulson, J.R. 1994. Releases of beneficial organisms in the United States and Territories-1983. Washington D.C: U. S. Department of Agriculture, Agricultural Research Service, $113 \mathrm{pp}$.

Fallahzadeh, M. and N. Saghaei. 2010. Checklist of Braconidae (Insecta: Hymenoptera) from Iran. Munis Entomology \& Zoology 5(1): 170186.

Ghahari, H., M. Fischer and J. Papp. 2011a. A study on the Braconidae (Hymenoptera: Ichneumonoidea) from Qazvin province, Iran. Entomofauna 32(9): 197-208.

Ghahari, H., M. Fischer and J. Papp. 2011b. A study on the braconid wasps (Hymenoptera: Braconidae) from Isfahan province, Iran. Entomofauna 32(16): 261-272.

Gupta, A. 2013. Revision of the Indian Microplitis Foerster (Hymenoptera: Braconidae: Microgastrinae), with description of one new species. Zootaxa 3620(3): 429-452.

Györfi, J. 1959. Neuere Beiträge zur Kenntnis der Wirte der Braconiden (Hymenoptera: Braconidae). Beiträge zur Entomologie 9(1-2): 140143.

Hedwig, K. 1961. Ergebnisse der Deutschen Afghanistan-Expedition 1956 der Landessammlungen für Naturkunde Karlsruhe. Ichneumonidae, Braconidae (Hymenoptera). Beiträge zur Naturkundlichen Forschung in Südwestdeutschland 19: 291-298.

Hegazi, E.M., G.M. Abdel-Aziz, A.Y. El-Shazly and W.E. Khafagi. 2007. Influence of host age and host deprivation on longevity, egg load dynamics and oviposition rate in Microplitis rufiventris. Insect Science 14: 485-495.

Hegazi, E., W. Khafagi and F. Schlyter. 2013. Egg maturation dynamics of the parasitoid Microplitis rufiventris: Starvation speeds maturation in early life. Physiological Entomology 38:233-240.

Inanç, F. 1997. The Microgastrinae (Hymenoptera: Braconidae) fauna of the Thrace region of Turkey. Turkish Journal of Zoology 21(2): 135165.

Inanç, F. 2002. A new species of Microplitis (Hymenoptera: Braconidae, Microgastrinae) from Turkey. Biologia 57(5): 563-566.

Inanç, F. and A. Beyarslan. 1997. Microgastrinae (Hymenoptera: Braconidae) species collected from some provinces of Gaziantep and Sanliurfa. Turkiye Entomoloji Dergisi 21(3): 213-223.

Inanç, F. and A. Beyarslan. 2001. A study on Microgastrinae (Hymenoptera: Braconidae) species in Gokceada and Bozcaada. Turkish Journal of Zoology 25(3) :287-296.

Janzen, D.H., A.K. Walker, J.B. Whitfield, G. Delvare and I.D. Gauld. 2003. Host-specific and hyperparasitoids of three new Costa Rican species of Microplitis Foerster (Hymenoptera: Braconidae: Microgastrinae), parasitoids of sphingid caterpillars. Journal of Hymenoptera Research 12: 42-76.

Khan, S.M. 1999. Effectiveness of Microplitis mediator (Hym.: Braconidae) against its hosts Agrotis segetum and A. ipsilon (Lepidoptera: Noctuidae). Pakistan Journal of Biological Sciences 2(2): 344-346.

Kotenko, A.G. 1994. On the braconid-fauna (Hymenoptera, Braconidae) of the Dahuria; pp. 79-89, in: A. G. Kotenko (ed.). Hymenopteran insects of Siberia and Far East: memoirs of the Daursky Nature Reserve, no. 3. Institut Zoologii NAN Ukrainy: Kiev.

Mason, W.R.M. 1981. The polyphyletic nature of Apanteles Förster (Hymenoptera: Braconidae): A phylogeny and reclassification of Microgastrinae. Memoirs of the Entomological Society of Canada 115:1-147.

Nixon, G.E.J. 1965. A reclassification of the tribe Microgasterini (Hymenoptera: Braconidae). Bulletin of the British Museum (Natural His- 
tory), Entomology Supplement 2: 1-284.

Nixon, G.E.J. 1968. A revision of the genus Microgaster Latreille (Hymenoptera: Braconidae). Bulletin of the British Museum (Natural History), Entomology series 22: 33-72.

Nixon, G.E.J. 1970. A revision of the northwestern European species of Microplitis Forster (Hymenoptera: Braconidae). Bulletin of the British Museum (Natural History), Entomology series 25: 1-30.

Papp, J. 1979. Braconidae (Hymenoptera) from Tunisia, 1. Folia Entomologica Hungarica 32: 175-87.

Papp, J. 1984. Palaearctic species of Microgaster Latreille (=Microplitis Förster) with description of seven new species (Hymenoptera, Braconidae, Microgastrinae). Entomologische Abhandlungen 47: 95-140.

Papp, J. 1986. First survey of the Glabromicroplitis Papp species of the Holarctic region, with taxonomic remarks of three Microgaster Latreille species (Hyrnenoptera, Braconidae: Microgastrinae). Annales Historico-naturales Musei Nationalis Hungarici 78: 249-53.

Rastegar, J., H. Sakenin, S. Khodaparast and M. Havaskary. 2012. On a collection of Braconidae (Hymenoptera) from East Azarbaijan and vicinity, Iran. Calodema $226: 1-4$.

Shaw, M.R. and T. Huddleston. 1991. Classification and biology of braconid wasps (Hymenoptera: Braconidae). Handbooks for Identification of British Insects 7(11): 1-126.

Shenefelt, R.D. 1973. Braconidae 5. Microgasterinae \& Ichneutinae. Hymenopterorum Catalogus (nova editio) 9: 669-812.

Song, D. and J. Chen. 2008. Five new species of the genus Microplitis (Hymenoptera: Braconidae: Microgastrinae) from China. Florida Entomologist 91: 283-293.

Telenga, N.A. 1949. Faunal list of parasites of the family Braconidae (Hymenoptera). Tadzhikistan. Entomologicheskoye Obozreniye 30: 381388.

Telenga, N.A. 1955. Braconidae, subfamily Microgasterinae, subfamily Agathidinae. Fauna USSR, Hymenoptera. Russia: USSR Academy of Sciences Publisher. 312 pp.
Tobias, V.I. 1971. Review of the Braconidae (Hymenoptera) of the U.S.S.R. Trudy Vsesoyuznogo Entomologicheskogo Obshchestva 54: 156-268.

Tobias, V.I. 1976. Braconids of the Caucasus (Hymenoptera, Braconidae). Opred. Faune SSSR. Leningrad: Nauka Press. 286 pp.

Tobias, V.I., N.A. Telenga and A.G. Kotenko. 1986. Subfamily Microgastrinae; pp. 605-815, in: G.S. Medvedev (ed.). Keys to the Insects of the European Part of the USSR Volume III, Hymenoptera Part IV. New Delhi: Amerind Publishing Co.

Tobias, V.I. and N.S. Saidov. 1992. Effect of wind on diel activity of parasitic hymenopterous insects (with braconid wasps as an example) (Hymenoptera Parasitica, Braconidae). Entomological Review 74(6): 114-122.

Tobias, V.I., M. Capek and P. Lauterer. 1998. Braconidae (Hymenoptera) from Afghanistan in the collections of the Moravian Museum. Acta Musei Moraviae Scientiae Biologicae 82:173-190.

van Achterberg, C. 1976. A preliminary key to the subfamilies of the Braconidae (Hymenoptera). Tijdschrift Voor Entomologie 119: 33-78.

van Achterberg, C. 1993. Illustrated key to the subfamilies of the Braconidae (Hymenoptera: Ichneumonoidea). Zoologische Verhandelingen (Leiden) 283: 1-189.

Wilkinson, D.S. 1930. A revision of the Indo-Australian species of the genus Microplitis Foerster (Hymenoptera: Braconidae). Bulletin of Entomological Research 21: 23-27.

Yu, D.S., C. van Achterberg and K. Horstmann. 2012. Ichneumonoidea 2011. (Biological and taxonomical information), Taxapad Interactive Catalogue, Ottawa. Accessible at http://www.taxapad.com/. Captured on 10 January 2014.

RECEIVED: January 2014

ACCEPTED: March 2014

Published online: May 2014

EDITORIAL RESPONSIBILITY: Benoit Guénard 